\title{
CONTINUOUS SUPPLIER RELATIONSHIP MANAGEMENT FRAMEWORK
}

\author{
Tilen Klobučar ${ }^{9}$ \& Jure Erjavec ${ }^{10}$
}

UDC / UDK: 005-057.188:339.372

JEL classification / JEL klasifikacija: M00

DOI: https://doi.org/10.22598/pi-be/2019.13.2.87

Preliminary communication / Prethodno prioćenje

Received / Primljeno: September 30, 2019 / 30. rujna 2019.

Accepted for publishing / Prihvaćeno za tisak: November 4, 2019 / 4. studenog 2019.

\section{Summary}

Procurement has become a key strategic business function for companies, which in turn has made supplier integration a key activity in supply-chain management. Thus, appropriate supplier relationship management is important in ensuring successful supplier integration and in determining the degree of integration. Scholars have developed various supplier relationship frameworks to support managers' efforts to manage their supplier relationships. However, no framework is suitable for every organization, and there is no guarantee that adopting and integrating a framework will lead to success. Each framework's benefits and drawbacks should be considered. In this paper, we review the most recent frameworks for supplier relationship management and then develop a new framework that addresses their issues. This proposed three-phase framework allows for greater flexibility and faster adaptation to the changes that occur in the turbulent business environment. The framework also allows for sufficiently detailed development of selected suppliers and enables buyer and suppliers to cocreate value. Additionally, with the help of appropriate IT support, the proposed framework facilitates continuous, stable and real-time data exchange, which in turn speeds up the decisionmaking regarding both operational and tactical procurement activities. This paper's

\footnotetext{
${ }^{9}$ Tilen Klobučar, Danfoss Trata, Slovenia, E-mail: tilen.klobucar@gmail.com

${ }^{10}$ Jure Erjavec, PhD, Assistant professor, Department of Business Informatics and Logistics, School of Economics and Business, University of Ljubljana, Slovenia, Email: jure.erjavec@ef.uni-lj.si
} 
main limitation is that the proposed framework builds on the analysis of shortcomings of previously developed frameworks and thus requires further validation.

Keywords: Supply chain management; Supplier relationship management; Supplier relationship management framework.

\section{INTRODUCTION}

Companies have traditionally regarded procurement as an administrative function, but this has begun to change in the last two decades. Companies are now paying more attention to key procurement activities as a way to meet increasingly complex market requirements. Simultaneously, they are beginning to expect more from suppliers in terms of the complexity of the purchased products and services; companies also have an ever-increasing need for knowledge sharing and joint development. Procurement has thus become a very important strategic function (Gustafsson and Jönsson, 2013).

The alignment of strategies for procurement and supply chain management is of great importance. Market needs and customer satisfaction should be taken into account when designing a supply-chain management strategy. Only when companies have a clear understanding of the market's requirements and limitations can they develop strategies to meet the needs of both their customers and all the stakeholders in the supply chain (Christopher and Towill, 2001).

Suppliers are important stakeholders in every supply chain. They can be integrated in various ways, but all of those methods are meant to improve the end customers' experience. However, these attempts to connect with suppliers typically have a very poor success rate unless the companies also manage to meet the suppliers' needs in the process. Supplier satisfaction must be taken into account because more satisfied suppliers do more to meet customers' needs (Wong, 2000). For example, the benefits of a reduced bullwhip effect are maximized when a company has high levels of both customer integration and supplier integration. In such cases, suppliers align their production plans with those of their customers (Lee et al., 1997). Additionally, a company that is closely connected with its customers can transfer information to its suppliers so that both groups' production and distribution plans can be aligned with the customers' realistic needs (Danese and Romano, 2011).

An important part of supplier integration is supplier relationship management (SRM); this determines the degree of integration and can be considered the basis of any successful integration (Lambert and Schwieterman, 2012). The degree of supplier integration that is most appropriate depends on the company's relationship with the supplier. A company thus must pursue a tailor-made strategy with each supplier. SRM 
has become a critical business process because of increases in market pressure, heightened expectations for long-term environmental sustainability, and the need for procurement savings (and thus enabled cost competitiveness); in addition, companies need to have strong relationships with key suppliers because they can provide the knowledge that the companies need to develop innovative solutions and to bring the resulting products to market in a timely manner (Lambert and Schwieterman, 2012). SRM can lead to lower inventories of purchased materials and of both semi-finished and finished products. It can also reduce a company's fixed costs by improving asset utilization and rationalization, enhancing investment planning, and eliminating redundancies (Lambert and Schwieterman, 2012).

Introduction of SRM framework requires companies in the supply chain to share resources and know-how; they also often must engage in joint usage of various properties such as warehouses and distribution centers (Oghazi et al., 2016). Such integration must occur on the organizational level, as it requires the exchange of not just data but also ideas, trust and concerted business-performance measurements (Forslund and Jonsson, 2009). Such integration presents many challenges, including security hurdles, inflexibility, integration costs, lack of trust, communication, common goals and interests, tools, commitment, or willpower; and differences in information technology (IT) or formalization level (Oghazi et al, 2016). Therefore, properly integrating such a framework requires first segmenting the suppliers according to predefined standards. This helps clearly define what the company expects from each supplier (and other relevant stakeholder) in terms of procurement, production, technology, research and development, management, and - above all - customer expectations. The aim is to segment suppliers based on their value over time so that opportunities for cocreating value with those suppliers can be identified (Lambert and Enz, 2012). Both supplier- and customer-based relationship management frameworks provide key connections throughout a company's supply chain (Lambert and Schwieterman, 2012).

Various SRM frameworks have been developed for companies to engage in relationship management with their suppliers, but no single framework is suitable for every organization. There is no guarantee that the adoption and integration of any SRM framework will be successful. Each framework's benefits and drawbacks need to be considered.

This paper focuses on three contemporary frameworks. The first framework (Lambert and Schwieterman, 2012) divides SRM into a strategic and operational part. The strategic part involves identifying which suppliers are critical to the company's success - both now and in the future. The operational part involves the establishment of cross-functional teams that work with each key supplier and that are split into segments. The second framework (Forkmann et al., 2016) covers the activities involved in 
establishing cooperation with new suppliers, developing and managing (i.e., enhancing) that cooperation and, finally, discontinuing such cooperation. The third framework (Park et al., 2010) focuses on four steps: constructing a procurement strategy, selecting suppliers and collaborating with them, evaluating the suppliers' performance and development, and delivering continuous improvement. This third framework also emphasizes the importance of IT support to producing a functioning SRM architecture. As we have already highlighted, each SRM framework has distinct advantages and disadvantages. However, they share an awareness that companies need to pay more attention to their relationships with suppliers. However, each framework is focused on improving SRM in a distinct way, comes from a distinct perspective and has a distinct business model. Most of the frameworks were designed with large multinational firms in mind. Although an increasing number of medium-sized companies (smaller business systems) need SRM frameworks, their respective constraints emerge from distinctive business needs and capabilities. Thus, in practice, the existing frameworks are imperfect and sometimes convoluted. These frameworks also neglect the importance of engagement and of combining key business functions in the formulation of procurement strategies; procurement interests are only briefly considered when determining the strategic paths for other key business functions. In addition, a growing number of advanced IT solutions can support business operations as a whole, thus enabling companies to reap the benefits of working closely with their suppliers. However, many companies are not leveraging these advantages. If companies seek to take advantage of close supplier collaboration in the long run, they need to devote sufficient resources to that task. It is vital to have a cross-functional team that works with suppliers, but many companies still see this as an unnecessary cost rather than an investment. There is still a need for a more adjustable framework that better suits the needs and capabilities of medium-sized companies.

The purpose of the paper is to develop a new SRM framework that addresses these issues with the existing frameworks.

The paper begins with a Literature Review section that describes the current research on SRM frameworks, including their benefits and drawbacks. The Methodology section describes the steps involved in developing the proposed framework - which is then discussed in the Framework Development section. Lastly, the Conclusion section provides an overview of the paper, describes its limitations and outlines how further research could validate the proposed framework. 


\section{LITERATURE REVIEW}

Most companies' goals are related to reducing costs, decreasing the number of suppliers, improving product quality, or shortening delivery times. One of the best ways to achieve supply chain excellence via procurement is to establish partnerships with various suppliers (Wong, 2000). For companies pursuing the above-mentioned goals, a key challenge involves deciding which suppliers to pursue a partnership with and which to have a more transactional relationship with (Van Weele, 2014). Modern, agile supply chains have complex and ever-changing requirements, but suppliers' needs are more rigid. It is quite challenging to find a supplier that is already organized to meet the company's complex customer requirements and that is also acceptable in terms of total cost of ownership. A much more efficient method involves developing suppliers' capabilities. The most critical factors in enabling this method include effective communication and the sharing of knowledge and information. When buyers and suppliers share information and together support the suppliers' development, these efforts can directly improve the quality of the buyers' products and services and can thus indirectly impact the buyers' financial performance. However, supplier support should not be limited to after a problem has surfaced; a company's approach must be proactive if it is to develop a strong supplier base (Carr and Kaynak, 2007). Buyers should maintain close long-term relationships with their suppliers in order to enable the funneling of valuable knowledge (Tseng, 2014). A company that has not set up formal processes for selecting and onboarding suppliers, measuring their performance, and managing supplier relationships can experience very negative repercussions in the buyer-supplier relationship (Oghazi et al., 2016). The processes need to be formalized, as this is a precondition for efficient and concerted operations that enable value funneling.

Effective and efficient SRM is the basis of successful supplier integration. Fogg (2009) defined SRM as the management of the relationship between a supplying entity and a buying entity; this is a two-way process that is meant to improve the performance of both companies. Herrmann and Hodgson (2001) described SRM as the management of strategic suppliers in order to reduce costs, increase the predictability and repeatability of procurement, provide experience with supplier integration, and leveraging the benefits of the relationship. Moeller et al. (2006) stated that SRM includes establishing, developing, stabilizing and dissolving supplier relationships, as well as observing suppliers; the aims of SRM are to generate and enhance value in those relationships. Several sources (Herrmann and Hodgson, 2001; Moeller et al.,2006; Lambert and Schwieterman, 2012) agree that devoting resources to SRM presents benefits such as reduced costs, increased access to new knowledge, technologies, enhanced idea 
generation, increased supply chain flexibility, improved availability, and shortened time to market.

Consequently, both SRM and its individual elements have a positive influence on performance for the supplier base and for the entire company. This impact is particularly reinforced in the current, turbulent business environment, which is characterized by demand unpredictability; as unpredictability increases, so too does the impact of SRM. Because the business environment is becoming increasingly turbulent, the development of appropriate SRM capabilities is not just a strategic option but also an essential condition for a company's success (Forkmann et al., 2016).

The same type of relationship management should not be applied to all suppliers. For example, when a supplier delivers a spectrum of standard products and multiple alternatives are available on the market, interaction is likely to be less frequent, the level of trust is lower, and the focus is primarily on negotiating the best possible commercial terms rather than on establishing a long-term close relationship. On the other hand, more strategically important suppliers need to be treated differently, using a clearly defined framework and the activities that emerge from it. However, it is not enough for these activities to be performed only by the procurement function; other key business functions and relevant stakeholders need to be included to ensure successful SRM. Relationship management is a skill that needs to be developed. It is also critical to improving the likelihood that a supply chain will perform well. Companies can seek to improve this skill by providing managers with intensive trainings, seminars and educational courses (Kwon and Suh, 2004).

As is typical of relationships between two partners, the buyer-supplier relationship requires frequent adaptation to meet mutual interests. Depending on the balance of power between the buyer and supplier, the partners may need to adapt their operations, processes and/or regular daily activities. However, because a supplier is economically dependent on its buyers, the supplier usually must be more capable of - and willing to - adapt, in relation to its buyers. Regardless, buyers must be careful not to put too much pressure on their suppliers, as this could compromise the suppliers' business performance and financial stability (even if it improves their own). Suppliers may perceive certain buyers' requirements and expectations as being in conflict with their own understanding of the relationship's roles and responsibilities (Murfield and Esper, 2016).

Some companies are already very aware of suppliers' importance - and the importance of managing relationships with them. For instance, to Honda, its suppliers are so important that managers at all levels study suppliers firsthand so as to better understand how the suppliers' businesses affect Honda (Won Lee et al., 2007). As their markets are similar and as they target similar customer groups, McDonald's and Coca-Cola have established a close, multilevel partnership; this long-term collaboration enables a stable 
flow of critical resources (Wang et al., 2016). Companies such as Dell and Walmart are well-known for collaborating closely with their suppliers and other partners (Singh and Power, 2009). Their years of collaboration provide good examples for how companies can take advantage of the opportunities presented by their supply-chain partners. As another example, consider Apple's well-documented strategy for purchasing processors. With the help of SRM, the company has continuously adapted its strategic approach to purchasing in this procurement category to match the state of the market and its suppliers' needs (Forkmann et al., 2016). Some companies also encourage the development of close, collaborative relationships between its first- and second-tier suppliers. For example, Toyota established an efficient just-in-time system using this approach (Huang et al., 2014).

Forming and maintaining high-quality relationships is a complex process that requires significant resources. Firms should view these relationships not as costs but as investments that generate the potential for future revenue (Fynes et al., 2004). Many companies (especially small and medium-sized ones) perceive SRM not as an investment but as an unnecessary expense. This is exactly why companies must utilize their pool of opportunities by, for instance, replacing less successful or outdated procurement techniques with an appropriate SRM framework that helps the company to not only discover existing ideas but also generate new ones.

Companies can choose from among quite a few theoretical frameworks when implementing SRM (e.g., Choy et al., 2003; Moeller et al., 2006, Forkmann et al., 2016, Lambert and Schwieterman, 2012, Park et al., 2010). No framework is clearly best, as each business model or procurement process is distinctly organized; thus, some degree of framework customization is always required - especially for medium-sized companies. The following subsections outline some of the most recently developed (publications in last decade) and most frequently cited frameworks according to Google Scholar.

\subsection{SRM as a macro-level business process}

When forming a framework, Lambert and Schwieterman (2012) began with the Global Supply Chain Forum research team's list of eight linked macro-level business processes: SRM, customer relationship management, customer service management, demand management, order fulfillment, production flow management, product development (and commercialization), and returned goods management. In this framework, SRM and customer relationship management serve as crucial linkages throughout the whole supply chain.

Lambert and Schwieterman (2012) divided these SRM processes into two categories: strategic and operational. The strategic processes relate to SRM design and strategic management, whereas the operational processes deal with SRM implementation 
and execution. Strategic processes are the responsibility of the management representatives from all of a company's important business functions. This category includes the following subprocesses: the review of corporate, marketing, manufacturing and sourcing strategies; the identification of criteria for supplier categorization; the creation of guidelines regarding the degree of customization in product or service agreements; the development of a framework for measuring suppliers' performance; and the establishment of guidelines for sharing process improvements with suppliers. By contrast, the operational subprocesses consist of differentiating suppliers, preparing teams to work with suppliers, conducting internal reviews of suppliers' teams, identifying the opportunities that suppliers present, constructing product or service purchasing agreements (i.e., contracts) and communication plans, implementing those agreements, measuring suppliers' performance, and generating reports on suppliers' costs and profitability. These operational activities are performed on a daily basis, and responsibility for them lies with the teams that are responsible for working with particular suppliers.

Strategic SRM essentially involves identifying which suppliers are key to the company's success, as well as which ones will be in the future; it also involves determining how to develop and maintain supplier relationships. Before engaging in operational SRM, the aforementioned teams for each of the key suppliers, as well as the shared team for other suppliers, must work with the suppliers and other groups to create custom-made, mutually beneficial product or service purchasing agreements. The goals are to segment the suppliers based on their value over time and to identify opportunities for value cocreation (Lambert and Schwieterman, 2012).

In particular, consider the last phase of strategic SRM, which involves sharing the benefits of process improvements with suppliers. This is a very important aspect of cooperation. Lambert and Schwieterman (2012) emphasized that the goal of this phase is to create a mutually beneficial situation for the buyer and the supplier. Unless both partners achieve positive results, the supplier is unlikely to commit to fulfilling the buyer's goals. The benefits of any improvements need to be quantified in financial terms.

\subsection{SRM capability: qualification and extension}

Forkmann et al. (2016) took the perspective that, to efficiently manage its supplier relationships, a company needs to implement processes and routines that focus on changing the supplier base. This approach coincides with the current, turbulent business environment. Forkmann et al. (2016) therefore focused on how to find and onboard new suppliers, how to develop existing ones and how to discontinue cooperation with those whose performance is continuously unsatisfactory. 
In this framework, SRM abilities are divided into three segments: Supplier Relationship Initiation Capability (SRIC), Supplier Relationship Development Capability (SRDC) and Supplier Relationship Ending Capability (SREC). Forkmann et al.'s (2016) findings indicate that all three segments positively influence the supplier base and, consequently, the buyer. This is especially true in the current, turbulent environment, which causes uncertainty in demand forecasting (Forkmann et al., 2016).

SRIC encompasses the initiation of new collaborations with suppliers - that is, the start of a relationship with a supplier, which includes the selection and attraction processes. The criteria for supplier selection vary by company and depend on its specific requirements. The attraction of new suppliers is based on how each supplier view the potential buyer and on the potential benefits of engaging in cooperation with the buyer; thus, reputation plays an important role. SRDC focuses on developing and managing relationships, such as by increasing collaboration with the existing suppliers that continuously perform well and that have a positive impact on supply-chain performance. SRDC improvements affect quality, deliverability and other important operation and performance indicators. The importance of informal (social) networking with suppliers is accentuated within SRDC, as this increases solidarity and trust while reducing opportunistic behavior. Nonetheless, when a supplier constantly demonstrates an inability to meet the buyer's requirements and or achieve the agreed-upon level of performance, the buyer needs to identify the issue and discontinue its cooperation in a timely manner. This leads to SREC. By terminating cooperation with suppliers, companies can also redirect their resources into the execution of their SRIC and SRDC. However, companies should be cautious when terminating cooperation with suppliers, as improper discontinuation may adversely affect the company's reputation and goodwill. SREC can also motivate existing suppliers to pay more attention to continuous-improvements initiatives, particularly if they know that termination is a realistic option if their performance is inadequate (Forkmann et al., 2016).

Forkmann et al. (2016) highlighted the benefits of SRM capability in a business environment with uncertain market demand. Companies in such environments are highly motivated to implement SRM, as any inability to satisfy their customers' requirements can result in the loss of market share and can ease competitors' market entrance. Changes in customers' needs require changes in the company's business processes, including in the management of the supplier base. Sometimes, the right answer is to develop the company's existing suppliers, but on other occasions, companies need to be able to terminate supplier relationships and find ones that better meet their current requirements. 


\subsection{An integrative framework for $S R M$}

Park et al. (2010) proposed an integrative framework for SRM that consisted of forming a procurement strategy, selecting suppliers, collaborating with suppliers, evaluating their performance, developing relationships with them, and ensuring their continuous improvement. This system supports activities by linking advanced planning and scheduling, enterprise resource planning, production scheduling, warehouse management systems, and product life-cycle management systems. In this SRM framework, companies should create efficient and effective interactions between these systems and should also ensure continuous improvement and development through data analysis.

After integrating all these SRM features, a company should select only those suppliers that align with its procurement strategy. Park et al. (2010) placed special focus on supplier selection and provided a wide range of selection criteria. Selected supplier and its contribution to company's success has to be analyzed through collaboration. Appropriate level of support and development is to be determined depending on the outcome of regular performance measurement. Park et al. (2010) emphasized the importance of decisions about the scope of supplier collaboration; the related considerations include the degree of supplier involvement in the new product development phase, the degree of information exchange, the contract length and contract management, and the level of price transparency. Initiatives for continuous improvement should be implemented using the "plan, do, check, act" principle (Park et al., 2010).

For purchasers and procurement managers, IT support is extremely important in fostering collaboration with suppliers and creating a functioning SRM system architecture. It plays a key role in collaborations with both internal and external stakeholders. Internal collaboration is primarily about cooperation between the company's production, procurement and marketing systems; information sharing among these groups must be fast, smooth and without disruption. The SRM framework must be effectively connected to these systems, and suppliers must be able to access live data through their user interface. The degree of data sharing depends on the relationship with each supplier; it can be strategic, collaborative or transactional (Park et al., 2010).

Park et al. (2010) argued that this type of SRM framework helps companies to reduce purchasing costs, guarantee on-time development of new products, maintain high quality and ensure that products are released to the market as quickly as possible. 


\section{FRAMEWORK DEVELOPMENT}

In the Literature Review section, we introduced three SRM frameworks and pointed out their key features and properties. The factors in the selection process included recency and number of citations in the scientific literature. Therefore, all the selected SRM frameworks were developed in the last decade and are widely cited on Google Scholar; each also relies on existing frameworks (e.g., Moeller et al., 2006).

In the following sections we firstly identify the benefits and drawbacks of each of the frameworks described in the Literature Review section. Furthermore, we identify the need for developing a new framework. We thus develop a new SRM framework that builds on previously developed frameworks and tries to address their deficiencies: continuous SRM (CSRM).

\subsection{Issues with the existing SRM frameworks}

Each of the three frameworks presented above have drawbacks. First, Lambert and Schwieterman (2012) already addressed some shortcomings of their framework at the end of their article; we focus on those that are connected to the need for a solution that better fits with the turbulence of the modern business environment. For example, Lambert and Schwieterman (2012) did not address the need to discontinue cooperation with suppliers. When business changes quickly, a company's needs also change quickly, so its supplier base sometimes needs to be redesigned. Lambert and Schwieterman (2012) also proposed forming a cross-functional team to deal with those suppliers that are not defined as key ones. From the financial perspective, the resulting human resources constraints and amount of procurement spending is hardly justifiable for many companies, especially those that are small or medium-sized.

With technological progress, the usage of improved IT solutions is also inevitable. These solutions need to be interconnected in real time and must offer the interested stakeholders the right data at the right time. IT is not given adequate focus in the frameworks of either Lambert and Schwieterman (2012) or Forkmann et al. (2016). The latter also does not include supplier segmentation in its system of supplier life-cycle management. Although each supplier has its own life cycle within the buyer's portfolio, the buyer's approach to managing these relationships needs to be differentiated, and that is not possible without proper segmentation. Park et al. (2010) heavily emphasized IT support and early supplier involvement in SRM. Even though both are important factors, focusing too narrowly and operationally on either can have its hindrances. For example, early supplier involvement depends on supplier segmentation, as well as on the company's level of development, size and availability of key resources. A company might not even require early supplier involvement if its supplier offer only relatively 
standardized or basic components and services. Park et al. (2010) did not address these factors when expressing the importance of early supplier involvement.

Furthermore, none of these existing frameworks expresses the need for closer cooperation between internal stakeholders. Tighter collaboration between key business functions within the strategy-alignment phase needs to be emphasized. The strategies of each business function need to be aligned and work toward a common goal that is established within the overall business strategy. All three frameworks fail to address this issue.

The introduction of closer collaboration and better cooperation between key business functions is thus the first step in the CSRM framework we propose in this paper. In existing frameworks, the differentiation in the managing relationships among various suppliers is often nonexistent. Any SRM framework that allows for limited differentiation also causes limited opportunities for the proper leveraging of suppliers' value. In addition, customers (irrespective of industry) tend to become more demanding over time. Their requirements thus become stricter and more complex, so businesses require more flexibility, greater product-portfolio diversity, and custom-made approaches. Last, but not least, price sensitivity also increases. Consequently, demand accuracy decreases, and both project sales and uncertainty increase. As market demands change, companies should alter their operations, especially in the context of supply chain management, which focuses on efficiently delivering the desired product to the end customer.

There are also some more positive similarities between the three frameworks. The main common denominator is the awareness that companies need to pay attention to their supplier relationships. All three frameworks also emphasize the importance of supplier development, of measuring suppliers' performance, and of adequately controlling the performance of the supplier base to meet the needs of the overall business strategy.

At the same time, each framework focuses on specific details of the business environment and of supplier relationships. Lambert and Schwieterman (2012) viewed SRM as part of a macro-level business process; in particular, their framework ascribes great importance to sharing cocreated benefits with suppliers. Forkmann et al. (2016) highlighted the SRM life cycle and assigned particular importance to that cycle in turbulent environments that lead to uncertain demand forecasts. Park et al. (2010) proposed integrating SRM systems with other key internal systems and providing suppliers with real-time access. Thus, all three of these frameworks contain certain aspects that can improve upon the others' weaknesses in the current, turbulent business environment. This study's proposed framework links these building blocks and adds a few key elements that provide for a better comprehensive fit. 


\subsection{CSRM Framework}

The proposed framework is divided into three intertwined phases that are carried out continuously and simultaneously. Each repeats on its own time frame - hence the use of "continuous" in the framework's name. The proposed CSRM framework is depicted in Figure 1.

The framework's first phase forms the basis in that it provides for the alignment of the procurement strategy with the strategies of all key business functions; it also includes supplier segmentation and performance analysis for the entire supplier base. This phase's processes need to be performed at least once per year. The second phase constitutes the core of the CSRM framework; it is essentially an extension of a crucial part of Lambert and Schwieterman's (2012) framework. The second phase specifically emphasizes the importance of having a cross-functional team that is specifically responsible for working with suppliers. The activities in this phase should be reviewed and executed regularly. Lastly, the third phase should be understood as the foundation of the framework, as it considers the so-called supplier life-cycle (which includes the initiation, development and discontinuation of relationships with suppliers). Status reviews and follow-ups should be performed several times per year. 


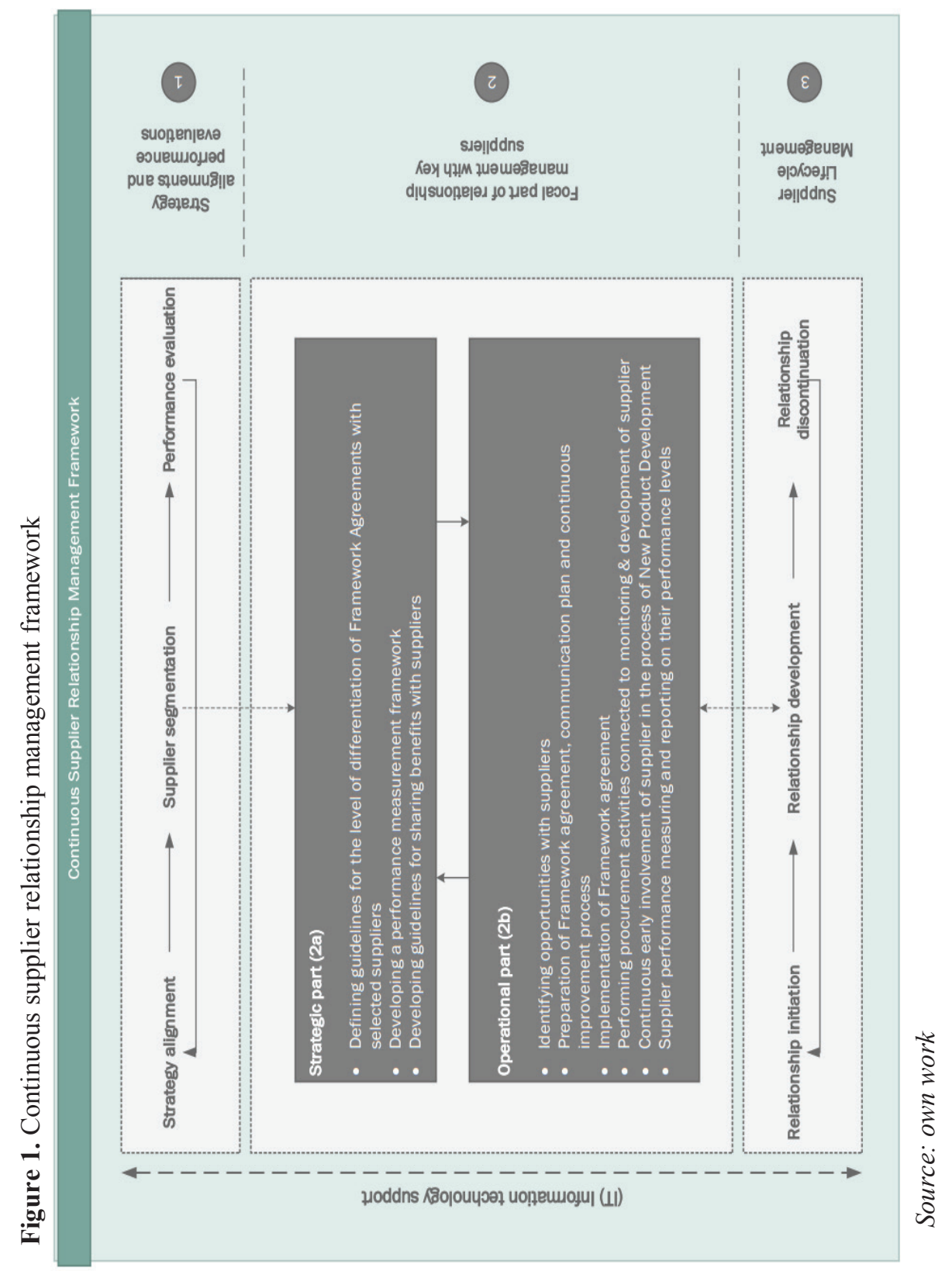




\section{First phase: Strategic alignment and performance evaluation}

The process begins with the joint preparation of the procurement strategy and the strategies for corporate, sales and marketing, production, and research and development - these strategies must be aligned. In practice, this enables the procurement department to influence decision-making and to contribute to other key business functions and viceversa (i.e., other business functions can contribute to strategic procurement planning). At this point, managers must identify any potential strategic opportunities for value creation, supply risks and strategic business goals; these must be factored into the strategicplanning process for procurement because suppliers can have a big influence on the finished products' quality, availability, time to market, cost, and so on. This phase enables the identification of business needs, which leads to more fluent supplier life-cycle management, as defined in the third phase.

Within this part of the framework, managers are responsible for supplier segmentation and for defining the strategic path that serves as an input for the segmentation process. The managers of the above-mentioned key business functions should make these decisions, as those functions are mutually dependent on suppliers' contributions. Procurement cannot be the sole business function involved in deciding how suppliers are segmented. The importance of each segmentation criterion varies by company. Consequently, each company should independently decide on its precise criteria and segmentation methods, depending on its requirements. As a result, we do not propose a dedicated solution within the CSRM framework; instead, we emphasize the importance of aligning the criteria and methods across all key business functions.

This phase's activities result in the selection of key suppliers, who then fall under the responsibility of the cross-functional team defined within second phase. Other suppliers are divided into segments (i.e., procurement categories), and the responsibility for relationship management and other strategic procurement activities lies with the strategic purchasers (category managers) and not with the cross-functional teams. This framework also divides a company's procurement processes into strategic and operational areas; the strategic area's work is organized based on category management principles.

Performance evaluation refers to the assessment of not just overall procurement performance but also how the suppliers' performance impacts the performance of the whole supply chain and of the company itself. It involves defining the objectives for each supplier segment and developing the measurement framework through which the yearly evaluations are conducted. Depending on whether preset targets are reached, this process can also provide inputs for strategy coordination and alignment. 


\section{Second phase - Focal part of relationship management with key suppliers}

This phase represents the backbone of the CSRM framework; it is the responsibility of the cross-functional team, the members of which are nominated by key managers. This team's members are engaged in activities within the scope of their job responsibilities. However, those activities are performed within the CSRM framework and with a special orientation toward supplier relationships. The team must consist of representatives from at least the following business functions: procurement, production technology, logistics (and operational procurement), research and development, and sales (supply chain). This group regularly interacts with suppliers and is primarily responsible for maximizing the mutual benefits that can arise from close collaboration. The active involvement of key business functions also enables much faster problem-solving for issues (regarding both quality and supply) that normally disrupt the supply chain.

This team's work is divided into strategic and operational portions. Each has its own activities (as explained below). These divisions are mostly based on similar aspects of Lambert and Schwieterman's (2012) framework, but we added certain elements from Park et al.'s (2010) framework and our own contributions. The suppliers that have the greatest impact on a company's success need to be addressed differently, so we created tailor-made method that is enabled with CSRM.

\section{Strategic part}

Defining guidelines for the level of differentiation of Framework Agreements with selected suppliers: Because key suppliers can vary greatly by size, production process, organizational complexity, and product or service complexity, no single contract template is best for all suppliers. In this context, the team develops possible alternatives - or modifications - to each supplier's Framework Agreement by considering both revenue and costs.

Developing a performance-measurement framework: At this point, the company can evaluate the supplier based on the general framework defined in the first phase; alternatively, the company can adapt this framework to the specific nature of the cooperation with a key supplier. For example, some suppliers have a greater influence on a company's productivity than others do, so the company must decide how to monitor these key suppliers in greater detail and continuously analyze their impact. It is also imperative that the company's goals differ depending on the supplier's procurement category, the complexity of the delivered components, and the production process.

Developing guidelines for sharing benefits with suppliers: The company must have a clear goal of sharing mutually realized process improvements with the respective suppliers. It is very difficult for a company to gain and maintain a supplier's trust and commitment if that supplier does not see clear benefits from the cooperation. The 
company thus must quantify these benefits financially and establish an agreement with each supplier to share those benefits over time.

\section{Operational part}

Identifying opportunities with suppliers: This part is crucial in team performance and involves working closely with suppliers to develop opportunities for improvement. This affects the performance of all business functions and all parts of the supply chain, so all team members must actively contribute and work with the suppliers. It is also desirable to set the targets so as to identify new opportunities, as well as to regularly monitor the suppliers' status. Opportunity-identification initiatives must be ongoing, and both buyers and suppliers must pay attention to them.

Preparation of Framework Agreement, communication plan and continuous improvement process: As mentioned before, a Framework Agreement can be custommade for a key supplier or standardized for other supplier segments. This agreement must be designed to be mutually advantageous and must attract commitments from the supplier and from all important business functions from both the buyer and their supplier. It is important to prioritize predefined opportunities and to design the best possible solutions if the implementation of all proposed processes is not possible. Continuous-improvement processes are an important part of any such agreement, as they are aimed at finding new opportunities, optimizing existing cooperation and eliminating potential disruptions. A communication plan must be prepared in conjunction with the supplier; this document defines all the key activities of the cooperation with that supplier, as well as a way of monitoring those activities.

Implementation of Framework Agreement: Regular (perhaps weekly) meetings should be held to analyze the status of each implementation. These meetings must also continue after implementation itself is complete so as to ensure that both sides successfully implement the agreement - especially the segments that are specific to the supplier in question.

Performing procurement activities connected to monitoring \& development of supplier: Any activities that strategic purchasers within category management usually carry out (as part of the third phase) must also be performed jointly by the key suppliers and the cross-functional team. This includes risk-management activities and tasks that are meant to ensure supplier or product compliance, continuous supply availability, or supplier development. These tasks lead to better performance. Commercial negotiations (e.g., those that are rapid or value-based) must be given special attention within this phase. Continuous early involvement of supplier in the process of new product development: Companies must consider each supplier's level of involvement. In many cases, suppliers serve as key partners because they bring access to the latest technologies and to fresh 
knowledge and innovations; suppliers can thus accelerate a company's productdevelopment and market-launch timelines. This can increase the firms' market share, prevent new competitors from easily entering the market, and so on. This kind of knowledge- and data-sharing requires a high degree of trust, especially between the research and development departments of the buyer and supplier, but it plays a crucial role in the successful early involvement of suppliers.

Supplier performance measuring and reporting on their performance levels: Any performance-measurement system should be transparent, systematic and include effective reporting to the company's management. The generated reports can demonstrate each key supplier's value to the senior management teams of both the buyer and the supplier. Value should be measured in a way that also considers costs, sales, and investments. Only in this way can improvements be recognized and rewarded. Efficient IT solutions can greatly improve success in this area if they enable effective data capturing and analysis.

\section{Third phase: Supplier Life-Cycle Management}

This phase considers the supplier life-cycle activities that are within strategic purchasers' area of responsibility. As explained above, SRM activities are divided into three groups: initiation, development and discontinuation. Initiation activities comprise steps such as market and supplier-candidate screenings, supplier and commercial quality assessments, and recommendations and decision-making regarding sourcing. Development of supplier is here referring to performing procurement activities connected to monitoring and development of supplier part, described in second phase; this ensures that all suppliers are part of the monitoring and development initiatives, regardless of how they are segmented. During life-cycle management, any suppliers that are no longer wellsuited to the company's business environment or needs can be detected. A supplier may choose to end a relationship with a buyer for various reasons; perhaps the supplier wants to move in a different strategic direction, or perhaps the buyer no longer fits its customer base.

At the same time, strategic purchasing also includes the responsibility for identifying the suppliers that are increasing in importance or capabilities. Therefore, it requires identifying the suppliers that could transition into a new phase in the future provided that management approves the change in segmentation, of course. In the current, turbulent environment, which is characterized by uncertainty in demand and by changing customer demands, procurement must be flexible and able to respond these changes; this is why the third phase's is crucial. Certain suppliers will never become key for various reasons - usually due to their lack of strategic importance. In this case, relationships should be built in such a way as to secure undisturbed and smooth cooperation. 
IT support is of great importance in all three phases of the CSRM framework. A company's IT system must effectively and efficiently interconnect all important systems and software and thus help each business function in the supply chain to efficiently execute its activities. However, it is not enough for IT support to interconnect internal stakeholders; it must also extend to external stakeholders (especially suppliers). Such a system should allow for differentiation as certain information is more important to some suppliers than to others. It also must be accessible to these suppliers in real time, through a supplier portal or another means of connection, as this access can provide real insights.

This CSRM framework does not just complement procurement; it optimizes organization, improves control over key suppliers, efficiently identifies opportunities, and enables fast implementation. It also improves responsiveness to the uncertainties that arise from the current, turbulent business environment.

\section{CONCLUSION}

In this paper, we reviewed some recently developed SRM frameworks. Based on the shortcomings of these frameworks - some of which their own authors had pointed out, but others that we identified - we proposed a new framework for SRM: the CSRM framework.

The proposed CSRM framework should allow for greater flexibility and faster adaptation to the changes present in the current, turbulent business environment. It allows for the sufficiently detailed development of selected suppliers and enables buyers and suppliers to cocreate value. Additionally, with the help of appropriate IT support, it facilitates continuous, stable and real-time data exchange, which in turn speeds up a company's decision-making for both operational and tactical procurement activities. At the same time, it grants the managers of key business functions a platform through which they can participate in the formation of each other's strategic initiatives, all while considering and abiding by the overall business strategy.

The proposed CSRM framework is meant to correct the shortcomings of existing frameworks, but it also needs to be further validated. We propose continuing this research by validating the framework using a multiple case study methodology; this will involve conducting interviews with both key internal stakeholders and external suppliers. 


\section{REFERENCES:}

1. Carr, A. and Kaynak, H. (2007). Communication methods, information sharing, supplier development and performance. International Journal of Operations \& Production Management, 27(4), pp.346-370. DOI: 10.1108/01443570710736958

2. Choy, K.L., Lee, W.B. and Lo, V. (2003). Design of an intelligent supplier relationship management system: a hybrid case based neural network approach. Expert Systems with Application, 24(2), pp.225-237 . DOI: 10.1016/S09574174(03)00009-5

3. Christopher, M. and Towill, D. (2001). An integrated model for the design of agile supply chains. International Journal of Physical Distribution \& Logistics Management, 31(4), pp.235-246. DOI: 10.1108/09600030110394914

4. Danese, P. and Romano, P. (2011). Supply chain integration and efficiency performance: a study on the interactions between customer and supplier integration. Supply Chain Management: An International Journal, 16(4), pp.220-230. DOI: 10.1108/13598541111139044

5. Fogg, M. (2009). Managing Purchasing and Supply Relationships. Stamford UK: Chartered Institute of Purchasing \& Supply.

6. Forkmann, S., Henneberg, S., Naudé, P. and Mitrega, M. (2016). Supplier relationship management capability: a qualification and extension. Industrial Marketing Management, 57, pp.185-200. DOI: 10.1016/j.indmarman.2016.02.003

7. Forslund, H. and Jonsson, P. (2009). Obstacles to supply chain integration of the performance management process in buyer-supplier dyads. International Journal of Operations \& Production Management, 29(1), pp.77-95. DOI: 10.1108/01443570910925370

8. Fynes, B., de Búrca, S. and Marshall, D. (2004). Environmental uncertainty, supply chain relationship quality and performance. Journal of Purchasing and Supply Management, 10(4-5), pp.179-190. DOI: 10.1016/j.pursup.2004.11.003

9. Gustafsson, D. and Jönsson, H. (2013). Managing Operation Supplier Relationships - A case study at a major appliances manufacturer. Lund University: Faculty of Engineering.

10. Herrmann, J.W. and Hodgson, B., 2001, October. SRM: leveraging the supply base for competitive advantage. In Proceedings of the SMTA International Conference, Chicago, IL (Vol. 1).

11. Huang, M., Yen, G. and Liu, T. (2014). Reexamining supply chain integration and the supplier's performance relationships under uncertainty. Supply Chain 
Management: An International Journal, 19(1), pp.64-78. DOI: 10.1108/scm-042013-0114

12. Kwon, I. and Suh, T. (2004). Factors Affecting the Level of Trust and Commitment in Supply Chain Relationships. Journal of Supply Chain Management, 40(2), pp.4-14. DOI: 10.1111/j.1745-493x.2004.tb00165.x

13. Lambert, D. and Enz, M. (2012). Managing and measuring value co-creation in business-to-business relationships. Journal of Marketing Management, 28(1314), pp.1588-1625. DOI: 10.1080/0267257x.2012.736877

14. Lambert, D. and Schwieterman, M. (2012). Supplier relationship management as a macro business process. Supply Chain Management: An International Journal, 17(3), pp.337-352. DOI: 10.1108/13598541211227153

15. Lee, H., Padmanabhan, V. and Whang, S. (1997). Information Distortion in a Supply Chain: The Bullwhip Effect. Management Science, 43(4), pp.546-558. DOI: $10.1287 / \mathrm{mnsc} .43 .4 .546$

16. Moeller, S., Fassnacht, M. and Klose, S. (2006). A Framework for Supplier Relationship Management. Journal of Business-to-Business Marketing, 13(4), pp.69-94. DOI: 10.1300/j033v13n04_03

17. Murfield, M. and Esper, T. (2016). Supplier adaptation: A qualitative investigation of customer and supplier perspectives. Industrial Marketing Management, 59, pp.96-106. DOI: 10.1016/j.indmarman.2016.02.004

18. Oghazi, P., Rad, F., Zaefarian, G., Beheshti, H. and Mortazavi, S. (2016). Unity is strength: A study of supplier relationship management integration. Journal of Business Research, 69(11), pp.4804-4810. DOI: 10.1016/j.jbusres.2016.04.034

19. Park, J., Shin, K., Chang, T. and Park, J. (2010). An integrative framework for supplier relationship management. Industrial Management \& Data Systems, 110(4), pp.495-515. DOI: 10.1108/02635571011038990

20. Singh, P. and Power, D. (2009). The nature and effectiveness of collaboration between firms, their customers and suppliers: a supply chain perspective. Supply Chain Management: An International Journal, 14(3), pp.189-200. DOI: $10.1108 / 13598540910954539$

21. Tseng, S. (2014). The impact of knowledge management capabilities and supplier relationship management on corporate performance. International Journal of Production Economics, 154, pp.39-47. DOI: 10.1016/j.ijpe.2014.04.009

22. Van Weele, A. J. (2014). Purchasing and Supply Chain Management (6th ed). London: Cengage Learning EMEA.

23. Wang, Y., Wang, N., Jiang, L., Yang, Z. and Cui, V. (2016). Managing relationships with power advantage buyers: The role of supplier initiated 
bonding tactics in long-term buyer-supplier collaborations. Journal of Business Research, 69(12), pp.5587-5596. DOI: 10.1016/j.jbusres.2016.03.066

24. Won Lee, C., Kwon, I. and Severance, D. (2007). Relationship between supply chain performance and degree of linkage among supplier, internal integration, and customer. Supply Chain Management: An International Journal, 12(6), pp.444-452. DOI: 10.1108/13598540710826371

25. Wong, A. (2000). Integrating supplier satisfaction with customer satisfaction. Total Quality Management, 11(4-6), pp.427-432. DOI: 10.1080/09544120050007733 


\title{
OKVIR ZA KONTINUIRANO UPRAVLJANJE ODNOSIMA S DOBAVLJAČIMA
}

\author{
Tilen Klobučar \& Jure Erjavec
}

\begin{abstract}
Sažetak
Nabava je postala ključna strateška poslovna funkcija za tvrtke, što je zauzvrat učinilo da je integracija dobavljača ključna aktivnost u upravljanju lancem opskrbe. Stoga je odgovarajuće upravljanje odnosima s dobavljačima važno za osiguravanje uspješne integracije dobavljača $i$ za određivanje stupnja integracije. Znanstvenici su razvili različite okvire odnosa s dobavljačima kako bi podržali napore menadžera u upravljanju odnosima s dobavljačima. Međutim, nijedan okvir nije prikladan za svaku organizaciju i nema garancije da će usvajanje i integriranje okvira dovesti do uspjeha. Treba uzeti u obzir prednosti i nedostatke svakog okvira. U ovom radu dan je pregled najnovijih okvira za upravljanje odnosima s dobavljačima i zatim razvijen novi okvir koji će se baviti njihovim problemima. Ovaj predloženi trofazni okvir omogućuje veću fleksibilnost $i$ brže prilagođavanje promjenama koje se događaju u turbulentnom poslovnom okruženju. Okvir također omogućava dovoljno detaljan razvoj odabranih dobavljača i omogućuje kupcu i dobavljačima stvaranje vrijednosti. Uz to, uz pomoć odgovarajuće informatičke podrške, predloženi okvir olakšava kontinuiranu i stabilnu razmjenu podataka u realnom vremenu, što pak ubrzava donošenje odluka u vezi s operativnim i taktičkim aktivnostima nabave. Glavno ograničenje ovog rada je u tome što se predloženi okvir temelji na analizi nedostataka prethodno razvijenih okvira $i$ stoga zahtijeva daljnju validaciju.
\end{abstract}

Ključne riječi: upravljanje lancem opskrbe, upravljanje odnosima s dobavljačima, okvir za upravljanje odnosima s dobavljačima. 